\title{
Anatomy of Cranberry Stem Gall and Localization of Bacteria in Galls
}

\author{
Violet M. Best, Archana Vasanthakumar, and Patricia S. McManus
}

Department of Plant Pathology, University of Wisconsin, Madison 53706.

Accepted for publication 1 July 2004.

\begin{abstract}
Best, V. M., Vasanthakumar, A., and McManus, P. S. 2004. Anatomy of cranberry stem gall and localization of bacteria in galls. Phytopathology 94:1172-1177.

Cranberry stem gall is characterized by tumors that girdle stems, thereby killing all distal leaves, flowers, and fruit. Bacteria that produce high levels of the plant growth hormone indole-3-acetic acid (IAA) are associated with and believed to cause cranberry stem gall. The anatomy of naturally occurring galls on woody cranberry plants and galls caused by inoculation of micropropagated cranberry plants with Pantoea agglomerans strain 4/99 was consistent with elevated levels of IAA in plants. Field galls exhibited hypertrophy and hyperplasia of tissue external to the
\end{abstract}

ABSTRACT vascular cambium, resulting in extensive stem swelling and splitting of the periderm. Similarly, galls on micropropagated plants contained enlarged cortical parenchyma cells. The current year's xylem vessels in field galls were narrow and dense compared with xylem vessels of healthy stems. Curved xylem elements apparently developed de novo within field galls and galls on inoculated plants. Cavities and fissures in both types of galls contained dense aggregates of bacteria. Treatment of micropropagated plants with synthetic IAA caused hypertrophy of cortical parenchyma and formation of adventitious roots. The results support the hypothesis that IAA-producing bacteria cause cranberry stem gall.

Additional keywords: plant anatomy, Vaccinium macrocarpon.
The large American cranberry (Vaccinium macrocarpon Ait.) is a woody evergreen vine indigenous to eastern North America. Most commercial plantings of cranberry are established by lightly disking vine cuttings into sand. With adequate moisture, cuttings produce adventitious roots, and in 2 to 3 years, form a dense carpet of prostrate stems, or runners, from which vertically oriented shoots, or uprights, arise. Uprights elongate by about 5 to $10 \mathrm{~cm}$ per year, and fruit are produced on the current year's growth. In most regions, fruit are harvested by flooding beds and then dislodging fruit with mechanical reels or rakes. In Wisconsin, beds are flooded again in early winter to form an ice layer to prevent low-temperature injury and desiccation. The flood is withdrawn in early spring, after which frost protection is accomplished either by sprinkler irrigation or reflooding.

Cranberry stem gall is characterized by regions of stem swelling up to several centimeters in length and small galls on woody runners and uprights $(9,18)$. Eventually galls girdle stems, killing all distal leaves, flowers, and fruit. This disorder has been referred to as stem canker or "beater damage," under the assumption that stem swelling was caused by wound callus tissue that developed following injury from harvest reels. Abnormally large numbers of bacteria $\left(10^{3}\right.$ - to $10^{4}$-fold greater than in healthy stems), but not other microbes, have been isolated from galls $(9,18)$ and the pathogenicity of several strains of bacteria has been demonstrated on micropropagated cranberry plants (18). The production in vitro of indole-3-acetic acid (IAA) by bacteria was positively correlated with gall formation (18). These findings suggests that IAA-producing bacteria cause cranberry stem gall, although attempts to reproduce symptoms on woody plants have not been successful (18).

Microscopic analyses of plant galls can provide direct information on the etiology of galls (e.g., by revealing disease or insect signs) and effects of disease on host plant anatomy. Examination

Corresponding author: P. S. McManus; E-mail address: psm@plantpath.wisc.edu

Publication no. P-2004-0913-02R

(c) 2004 The American Phytopathological Society of the anatomy of disease galls sheds light on pathogen biology, symptom development, and structural defects that lead to plant decline. For example, early microscopic work on knot disease of olive (15), caused by Pseudomonas savastanoi, established that the pathogen colonizes xylem vessels and fissures within galls. Later studies showed that Pseudomonas savastanoi colonizes and spreads through laticifers of oleander, accounting for the numerous secondary galls that developed after inoculation at a single point (20). Aloni et al. (5) described the effects of Agrobacterium tumefaciens, the crown gall pathogen, on stem vascular tissues of castor bean. From their microscopic observations and knowledge of hormones that control vascular differentiation, they proposed the "gall constriction hypothesis" to explain the mechanism by which shoots distal to galls are deprived of water (5).

The overall goal of the current study was to identify anatomical features of cranberry stem gall that might further our understanding of the etiology and development of the disease. To this end, we used light microscopy to observe (i) cranberry galls collected from the field; (ii) micropropagated plants inoculated with Pantoea agglomerans, a probable stem gall pathogen (18); and (iii) cranberry plants treated with synthetic IAA. We also report the presence of bacteria in gall samples from the field, further demonstrating their close association with and likely role as the cause of cranberry stem gall.

\section{MATERIALS AND METHODS}

Field samples. Healthy and galled cranberry stems were sampled in 2002 from beds on three commercial cranberry farms located in central Wisconsin. Sampling dates were 20 June and 11 September at site 1, 25 July and 11 September at site 2, and 13 November at site 3. Most stem samples were collected from cv. Stevens, but a few stems of cv. Ben Lear were collected from site 1 on both dates. Samples were held on ice during transport to the laboratory. Healthy and galled stems (cv. Stevens) also were collected from three cranberry farms in Massachusetts in late August 2003 and shipped without ice to Wisconsin. 
Micropropagated cranberry plants-inoculation and treatment with synthetic IAA. Cranberry plants were propagated as described previously (18). Plants were inoculated with Pantoea agglomerans 4/99, which originally was isolated from cranberry galls (18). Six to ten plants were wounded at the third internode from the apical meristem with a sterile 27 -gauge needle. Bacteria were grown on Luria-Bertani medium for 24 to $48 \mathrm{~h}$ and then smeared onto the wounded region of the plant with a toothpick. Inoculated plants were placed in fresh Woody Plant Medium (PhytoTechnology Laboratories, Shawnee Mission, KS) and incubated at $27^{\circ} \mathrm{C}$ with a 12 -h photoperiod provided by fluorescent lamps. Wounded plants were treated with $1 \mu \mathrm{l}$ of $50 \%$ ethanol containing $0,0.1,0.5,1.0,5.0$, or $10.0 \mu \mathrm{g}$ of synthetic IAA (Sigma Chemical, St. Louis, MO). Samples were processed for microscopy 4 to 6 weeks after inoculation with bacteria or treatment with IAA.

Preparation of samples for microscopy. A protocol described by Ruzin (14) was adapted for cranberry stems. Stems were cut into 2-cm-long segments and immediately submerged in methanol/glacial acetic acid fixative $(3: 1, \mathrm{vol} / \mathrm{vol})$. Fixation was enhanced by vacuum infiltration of the samples for 18 to $20 \mathrm{~h}$. Fixative was removed, and samples were stored in $70 \%$ ethanol. Prior to embedding in paraffin, samples were dehydrated in $95 \%$ ethanol followed by absolute ethanol. The solvent was switched to tertiary butanol and then to molten paraffin. Samples were embedded in paraffin and the blocks were allowed to solidify overnight. Sections $(12 \mu \mathrm{m}$ in thickness) were cut on a rotary microtome, floated onto gelatinized microscope slides, and dried at $40^{\circ} \mathrm{C}$ for several hours. Paraffin was removed from sections by soaking slides in three changes of xylene for $30 \mathrm{~min}$ each. The xylene was removed and the sections were rehydrated by passing the slides through a descending series of ethanol. Slides were soaked in two changes of distilled water and then stained for $5 \mathrm{~min}$ in $0.01 \%$ (wt/vol) safranin O. After rinsing twice with distilled water, slides were dehydrated in an ascending ethanol series to $95 \%$ ethanol and counter-stained in $0.05 \%$ (wt/vol) fast green (dissolved in $95 \%$ ethanol) for $1 \mathrm{~min}$. Slides were rinsed three times in absolute ethanol and then moved through three changes of xylene. To detect suberin, which is typically associated with wound periderms $(6,8,13)$, sections were stained in $0.1 \%$ neutral red in phosphate-buffered saline $(0.01 \mathrm{M}$ potassium phosphate, $0.14 \mathrm{M} \mathrm{NaCl}, \mathrm{pH}$ 6.5) for $1 \mathrm{~min}$ and rinsed twice in water. Coverslips were placed on sections mounted in Permount (Fisher Scientific Co., Hampton, NH), and slides were allowed to dry before examination.

Microscopy. Sections were examined with an epifluorescent microscope (Olympus BH-2; Leeds Precision Instruments, Minneapolis, MN) equipped with an FITC filter (BP $490 \mathrm{~nm} / 515 \mathrm{~nm}$ LP) and a DAPI filter (UG-1 330-385 nm/435 nm LP). Observations were carried out with white or fluorescent light. Digital images were captured with an Optronix camera (Optronix, Goleta, CA). Observations were made on sections of eight, six, and six galled stems from Wisconsin field sites 1, 2, and 3, respectively, and two galled stems from each of the three sites in Massachusetts, for a total of 26 galls. As controls, sections from at least one healthy stem from each site in Wisconsin and one healthy stem from Massachusetts were observed. Observations were made on sections of 17 micropropagated plants inoculated with $P$. agglomerans $4 / 99$ and three plants that were not inoculated.

\section{RESULTS}

Healthy stems-field samples. Cross sections of stems showed that cranberry has diffuse porous wood (Fig. 1A) with narrow (5- $\mu \mathrm{m}$ diameter) and wide (10- to $20-\mu \mathrm{m}$ diameter) vessels dispersed evenly between early- and late-season xylem (Fig. 1B). In stems collected in June and July, a distinct vascular cambium was not easily discerned between xylem and phloem tissues, but radially flattened cambial cells were clearer in stems harvested in September and November (data not shown). The cortex was a few cell layers thick and not easily distinguished from primary phloem. A single, well-developed periderm, consisting of phelloderm, phellogen, and phellem, was observed in 1-year-old and older woody stems (Fig. 1B). The phelloderm consisted of two to four layers of relatively thick-walled cells that were usually aligned in radial files. The phellogen could not be discerned clearly. The phellem consisted of two to four layers of radially flattened cells.

Diseased stems-field samples. Gall anatomy varied among field samples (Fig. 2). However, certain features were common among most samples, regardless of collection date and site. Cells in affected stems underwent hypertrophy and hyperplasia, resulting in extensive stem swelling. The diameter of stems with galls ranged from 1.8 to $3.6 \mathrm{~mm}$ compared with 1.2 to $1.7 \mathrm{~mm}$ for healthy stems. In diseased stems, the periderm was split and pushed away from the stem by galls (Fig. 2). The origin of the thin-walled, parenchymatous cells that comprised galls was not clear. In many samples the phloem ring was disrupted, and it appeared that phloem cells might have differentiated into cells of gall tissue. Most galls contained some xylem tissue that had originated from the vascular cambium in the current year, but the vessels were more numerous and narrower than vessels produced in previous years (Fig. 2) or in healthy stems. Vessels in nongalled regions of the stem adjacent to galls were also narrow (data not

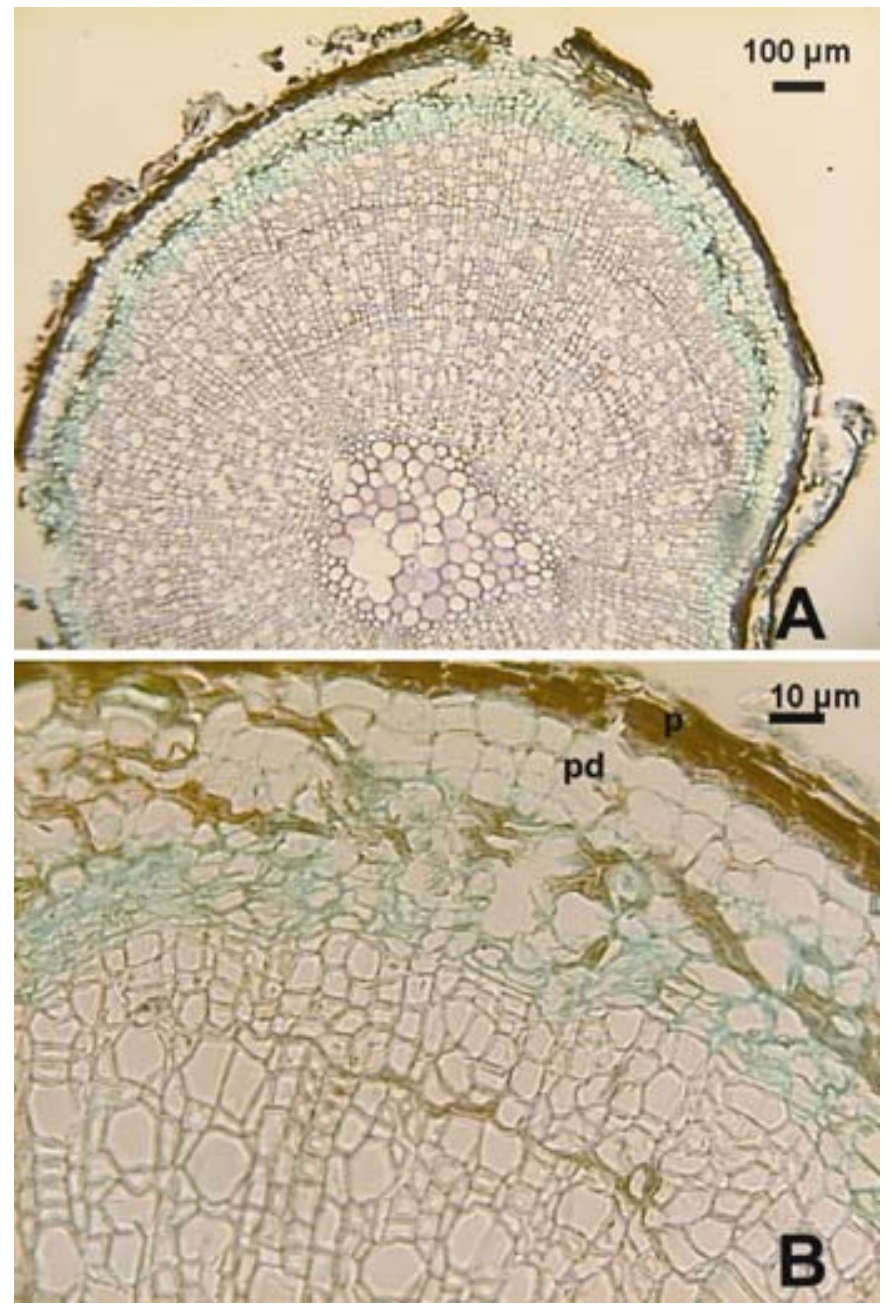

Fig. 1. Cross sections of healthy cranberry stems collected in June. Sections were embedded in paraffin, cut on a rotary microtome, stained with safranin/ fast green, and viewed with white light. A, Low magnification showing diffuse-porous nature of cranberry wood. B, Higher magnification showing phelloderm ( $\mathrm{pd}$ ) and phellem (p) cells of the well-developed periderm. 
shown). Xylem elements frequently were observed isolated within gall tissue, where they apparently developed de novo rather than from the vascular cambium (Fig. 3). However, by examining serial cross and longitudinal sections, it was often possible to determine that xylem in galls was contiguous with xylem of the stem axis.

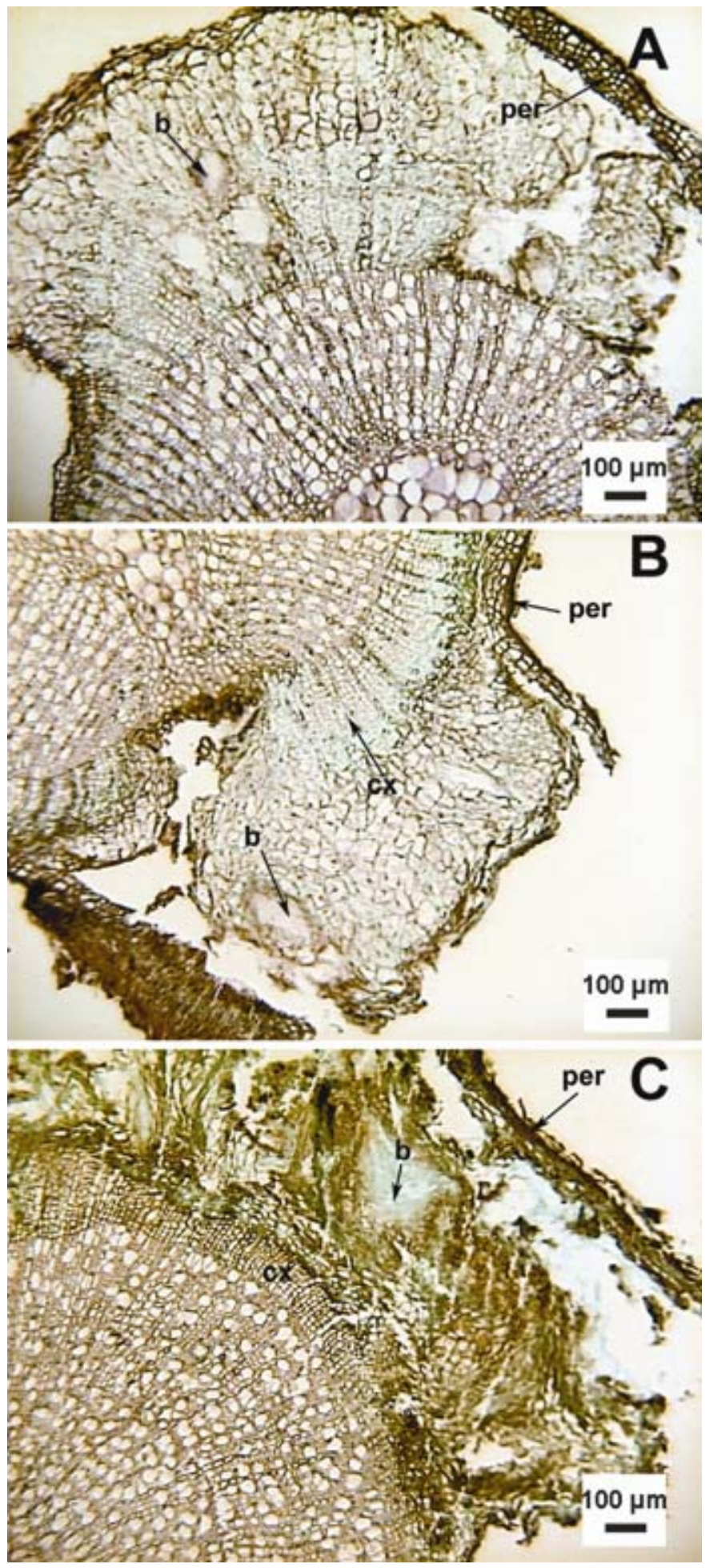

Fig. 2. Cross sections of cranberry stems with galls collected in A and B, June or $\mathbf{C}$, September. Sections were embedded in paraffin, cut on a rotary microtome, stained with safranin/fast green, and viewed with white light. A welldeveloped periderm (per) is pushed away from stems by the underlying galls. Bacteria (b) appear as cloudy masses staining $\mathbf{A}$ and $\mathbf{B}$, pink or $\mathbf{C}$, blue. The vessels of the current year's xylem (cx) are narrower and more numerous than vessels produced in previous years.
Upon treatment with the neutral red stain, which was indicative of suberin, narrow red bands were detected surrounding phelloderm cells (data not shown). Suberized tissue was visible at the edges of galls and covering leaf scars but not within galls or between gall tissue and the previous year's normal tissue (data not shown).

Localization of bacteria within field galls. Masses of rodshaped cells, approximately $1.2 \mu \mathrm{m}$ in length, were noted in fissures and cavities within all field galls. At lower magnification (Figs. 2 and 4), cells appeared as cloudy masses stained pink or blue. At higher magnification, individual cells were discerned (Fig. 5). Such cells were never seen in healthy stem sections. Large fissures containing rod-shaped cells were frequently, although not always, found near leaf traces (Figs. 2B and 4B). There were no signs (e.g., hyphae, fruiting bodies, or resting structures) of other microbes or insects that were consistently associated with stem galls in samples collected from the field during June through November.

Micropropagated plants inoculated with $P$. agglomerans. As with field samples, stems inoculated with $P$. agglomerans 4/99 varied in degree of tissue proliferation, but certain characteristics were common to most stem sections. Cortical parenchyma cells were enlarged, especially near the outer margins of galls, where they frequently measured 25 to $100 \mu \mathrm{m}$ in diameter (Fig. 6A) compared with 8 - to $12-\mu \mathrm{m}$ diameter in uninoculated control stems (Fig. 6B). Rod-shaped cells, presumably bacterial
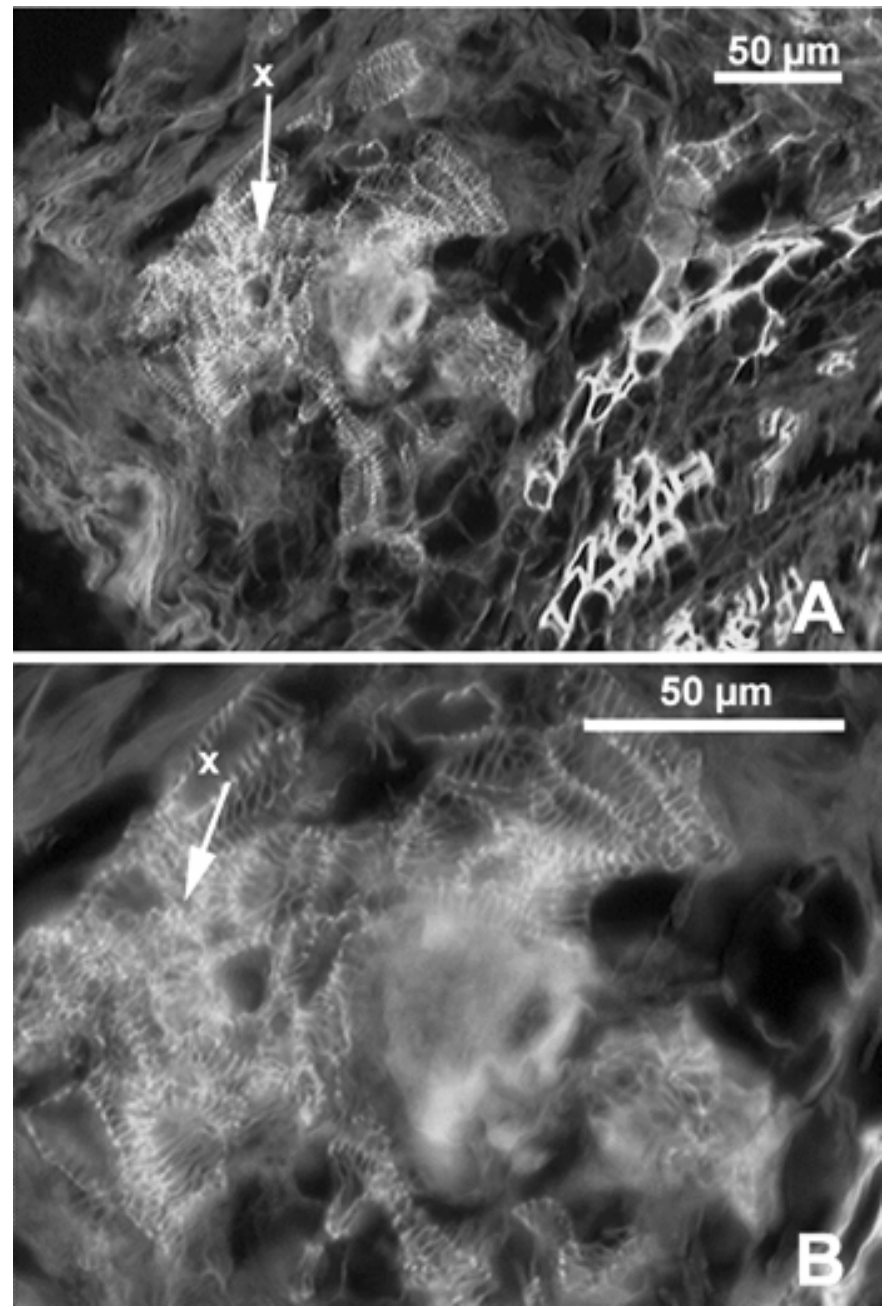

Fig. 3. Cross section of a cranberry gall at $\mathbf{A}$, lower and $\mathbf{B}$, higher magnification showing swirled xylem (x) that appears to have differentiated in the gall rather than from the vascular cambium. The section was embedded in paraffin, cut on a rotary microtome, stained with safranin/fast green, and viewed with fluorescent light. 
inoculum, were present in elongated masses between the main stem axis and gall tissue (Fig. 7) and in fissures within galls. In larger galls, isolated xylem elements developed within galls (Fig. 7).

Micropropagated plants treated with synthetic IAA. Treatment of stems with IAA at concentrations ranging from 0.5 to $10.0 \mu \mathrm{g} / \mathrm{ml}$ resulted in hypertrophy of cortical parenchyma cells, which measured 25 to $50 \mu \mathrm{m}$ in diameter (Fig. 8). Phloem tissue was not notably altered by treatment of stems with IAA. Adventitious roots developed at IAA concentrations ranging from 0.5 to $10 \mu \mathrm{g} / \mathrm{ml}$, with the greatest response at the highest dose. Unlike field samples and stems inoculated with bacteria, isolated xylem elements and bacterial masses were not detected in IAA-treated plants.

\section{DISCUSSION}

Several anatomical features of cranberry stem gall are consistent with our hypothesis that IAA-producing bacteria cause stem gall (18). Field galls, plants inoculated with P. agglomerans, and plants treated with synthetic IAA all showed extensive hypertrophy and/or hyperplasia of cortical and/or phloem cells (Figs. 2, 6, and 8). Similar abnormal cell development, especially hypertrophy, in several other plant gall disorders has been attributed to IAA production by bacterial pathogens $(5,11,12,17,19,20)$. Altered xylem anatomy in cranberry stem galls suggests a major
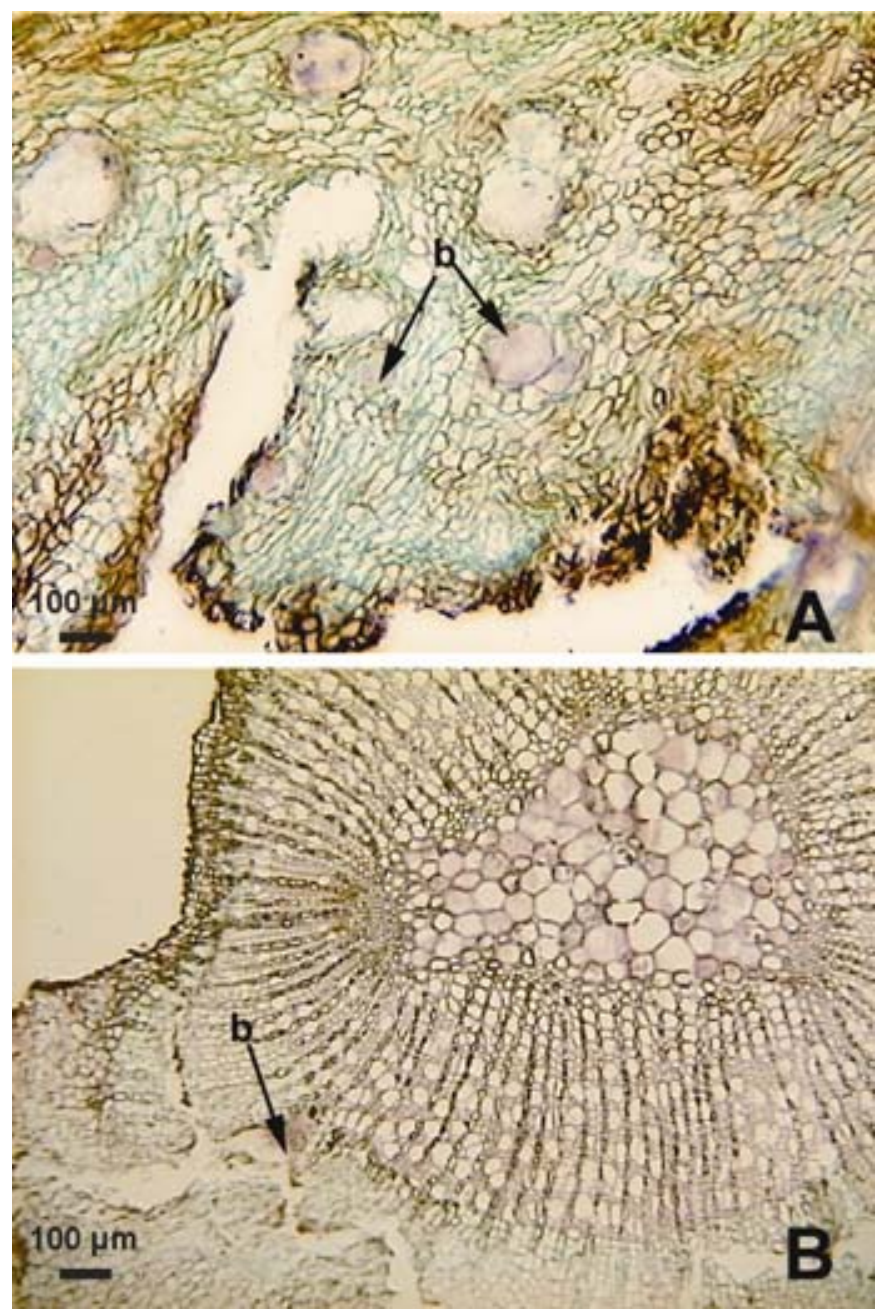

Fig. 4. Cross sections of cranberry galls showing bacteria (b) A, in cavities and $\mathbf{B}$, in a fissure near a leaf trace. Sections were embedded in paraffin, cut on a rotary microtome, stained with safranin/fast green, and viewed with white light. role for auxin, the main regulatory factor in vascular differentiation (1). Elevated levels of IAA are known to induce production of ethylene, which in turn causes increased vessel density and decreased vessel size (4). We observed this pattern in the current

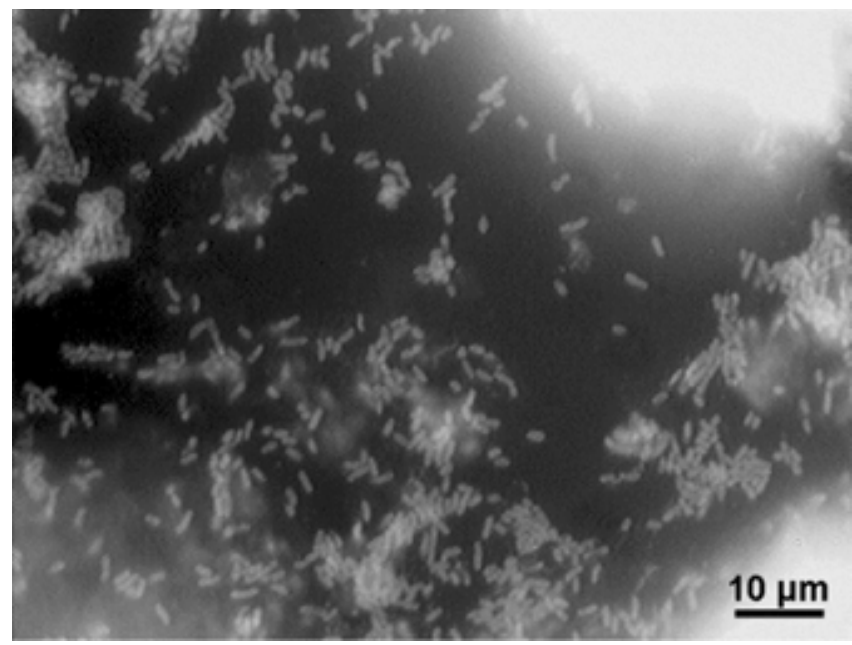

Fig. 5. Bacteria within a cranberry gall. The section was embedded in paraffin, cut on a rotary microtome, and viewed with fluorescent light. Intense fluorescence of plant tissue is seen in the upper right and lower right corners of the micrograph.

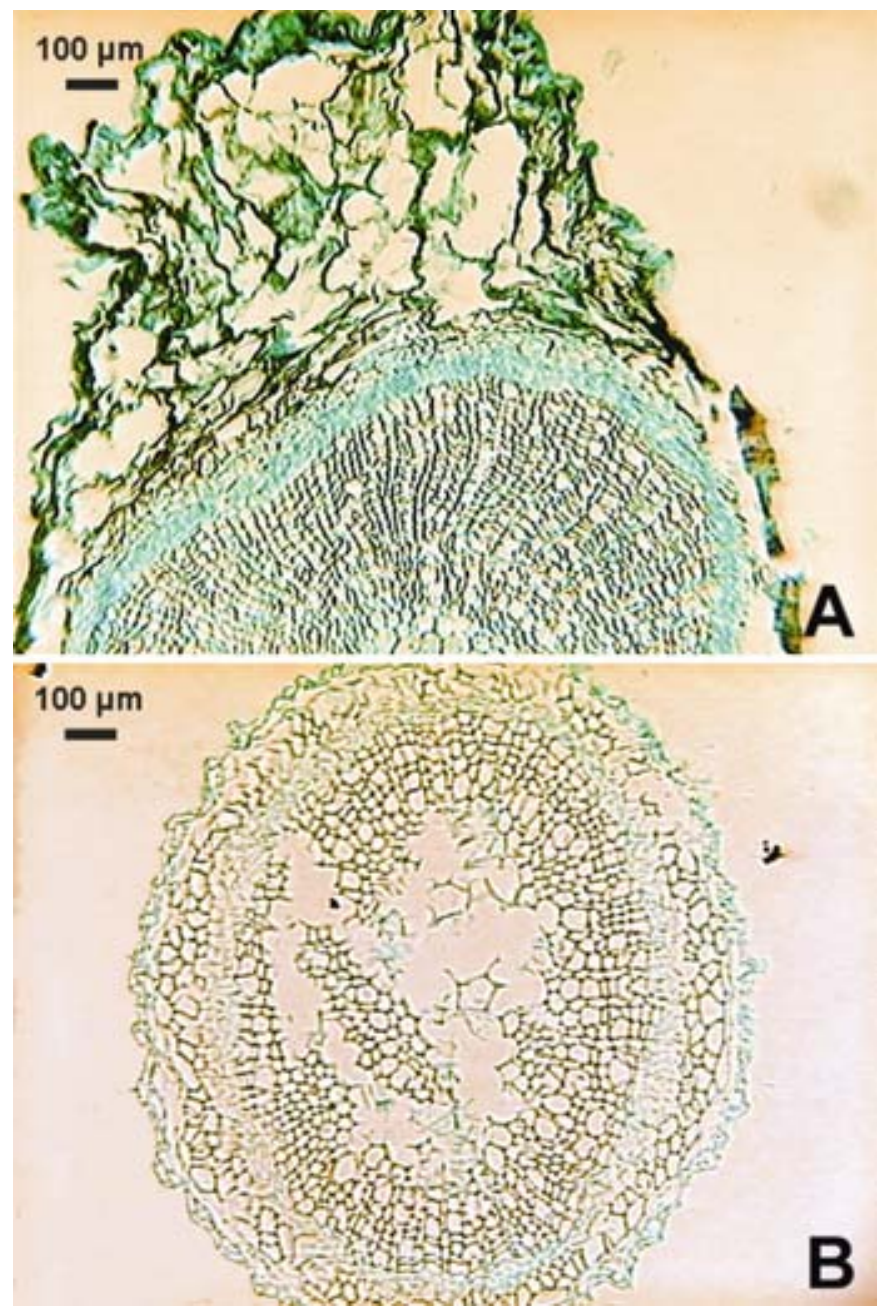

Fig. 6. Cross section of $\mathbf{A}$, a gall on a stem of a micropropagated cranberry plant inoculated with Pantoea agglomerans 4/99 and B, an uninoculated stem. Sections were embedded in paraffin, cut on a rotary microtome, stained with safranin/fast green, and viewed with white light. The large clear gaps in the xylem of the uninoculated stem $(\mathbf{B})$ are an artifact of sectioning. 
year's xylem growth ring in field samples (Fig. 2). In a previous study, application of auxin to ring-porous trees at the time of budbreak limited the size of earlywood vessels, thereby resulting in a diffuse-porous wood (2). In the case of cranberry stem gall, it appears that vessel diameter is also limited as soon as the vascular cambium becomes active in the spring; galled areas of stems pro-

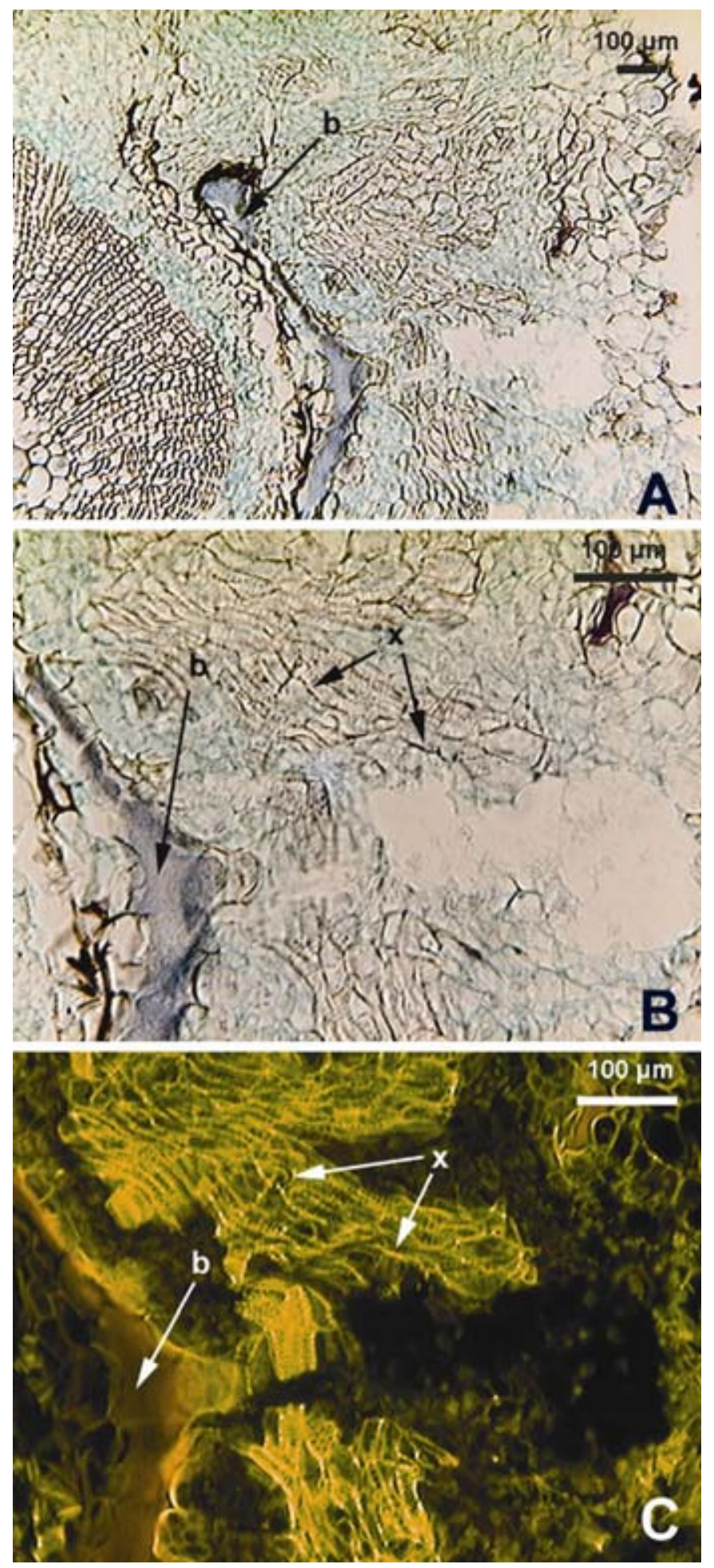

Fig. 7. Cross section of a gall on a stem of a micropropagated cranberry plant inoculated with Pantoea agglomerans 4/99 viewed at A, lower and B and C, higher magnification. The section was embedded in paraffin, cut on a rotary microtome, stained with safranin/fast green, and viewed with $\mathbf{A}$ and $\mathbf{B}$, white or $\mathbf{C}$, fluorescent light. A and B, Under white light, bacteria (b) appear as purple-stained masses within the gall. Xylem (x) appears to have differentiated within the gall. duced no normal-sized vessels in the year of gall formation. In addition to alterations in xylem originating from the vascular cambium, vessels apparently differentiated de novo within galls of field stems and inoculated plants (Figs. 3 and 7). Wilson (19) and Wilson and Magie (20) reported differentiation of vessels in galls of oleander knot, and later work proved elevated levels of IAA in galls (17). De novo differentiation of circular vascular tissue in crown galls on castor bean was attributed to auxin, presumably IAA in cells transformed by A. tumefaciens (5).

Because of the key role of bacterial IAA in numerous plant gall maladies, we studied IAA production by bacteria associated with cranberry stem gall (18). However, cytokinins also are important in development of some plant galls $(5,12,17)$ and could be involved in cranberry stem gall. A comparison of galls caused by bacteria versus the stem swelling caused by treatment of plants with synthetic IAA provides indirect evidence for cytokinin activity in cranberry stem gall. Cytokinin is produced in roots and is a limiting and controlling factor in differentiation of vascular tissues (3). Adventitious root development, which is favored by a relatively high ratio of auxin to cytokinin (3), was prolific on plants treated with IAA (18) (Fig. 8), less common on plants inoculated with bacteria, and rare on field galls. We propose that field samples and inoculated plants would be supplied with cytokinin from the bacteria that infect them. Also, field plants would have numerous roots, which would provide additional cytokinin. By contrast, root development is sparse in the tissue culture medium, which presumably results in low cytokinin levels in micropropagated cranberry plants. Therefore, with little or no cytokinin to counterbalance the effects of IAA, adventitious roots proliferated on IAA-treated plants. Furthermore, in galls caused by bacteria (Figs. 3 and 7), presumably the presence of bacterial-produced cytokinins allowed differentiation of xylem tissue, whereas xylem did not develop among the hypertrophic cells of plants treated with synthetic IAA (Fig. 8).

We detected masses of rod-shaped cells, which we presumed to be bacteria, in galls on field stems and plants that had been inoculated but not in healthy stems (Figs. 2, 4, and 5). The assemblage of bacteria in large fissures and cavities within galls resembles the bacterial cavities and fissures of Pseudomonas savastanoi in its hosts $(15,19)$. In field galls, bacteria were the shape and size of genera in the family Enterobacteriaceae (10), a bacterial taxon commonly isolated from field galls and capable of inducing symptoms when inoculated into plants (18). In galls on micropropagated plants, the cells were presumed to be the $P$. agglomerans 4/99 inoculum and appeared identical to cells in field

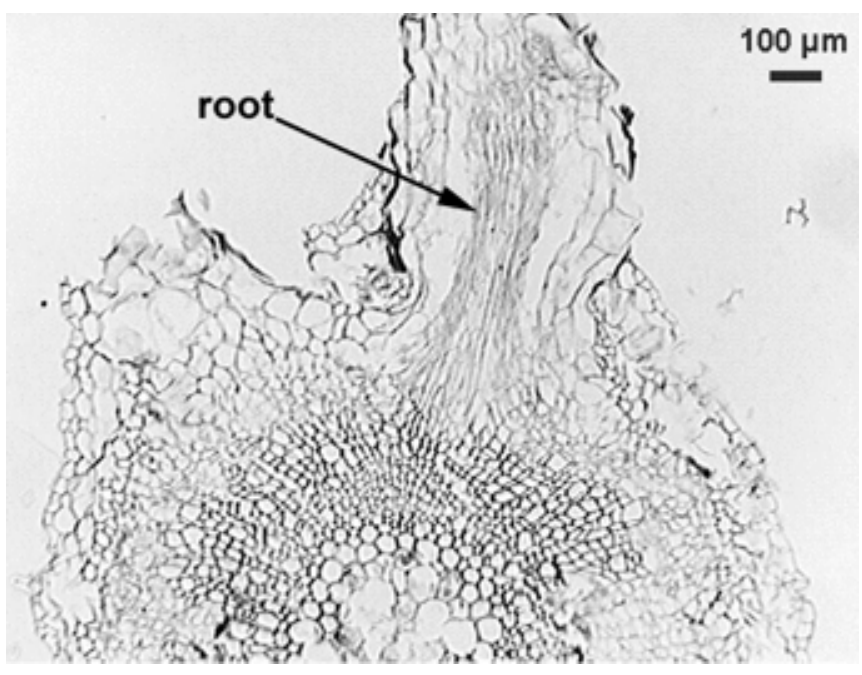

Fig. 8. Cross section of a stem of a micropropagated cranberry plant wounded and treated with synthetic indole-3-acetic acid $(5.0 \mu \mathrm{g} / \mathrm{ml})$. An adventitious root is labeled. 
samples. We attempted to identify the bacteria in situ with fluorescein-tagged eubacterial and Enterobacteriaceae-specific probes but were thwarted by autofluorescence of bacteria. Successful in situ hybridization to specific probes would provide valuable insight into the identity of the stem gall pathogen(s), infection courts, and pathogen colonization of plant tissues. Because autofluorescence is a problem, we are considering nonfluorescent labels for in situ hybridization.

Based on the findings of the current study, the occurrence of IAA-producing bacteria in cranberry beds (18), and field observations, we propose the following scenario for infection by bacteria, symptom development, and subsequent death of cranberry tissues distal to galls. Stem gall is often detected at the ends of beds where plants are in contact with harvest reels for relatively long periods of time as the machinery turns. Prolonged contact with reels could result in stem injury or excessive leaf drop. Also, significant leaf loss is often noticed in early spring when floodwater is removed. Therefore, bacteria likely enter stems through wounds (e.g., from harvest machinery or low-temperature injury) or leaf abscission zones. We frequently noted bacterial fissures and galls at leaf traces (Figs. 2B and 4B), although it was impossible to discern where the gall originated in the well-advanced galls from the field. Regardless of the infection court, two lines of evidence support our observation that bacteria enter plants sometime between harvest in the fall and budbreak in the spring. First, we observed macroscopically thousands of stems from approximately 20 sites between 1996 and 2003 and never detected stem galls on the current year's growth. However, the development of galls on micropropagated plants suggests that primary growth is not inherently resistant. Rather, these observations suggest that in the field, infection occurs and symptom development is initiated prior to the emergence of new growth. Second, the current year's earlywood vessels in galls were dense and numerous, suggesting that abnormal growth occurred as soon as the vascular cambium resumed activity. The vascular cambium is particularly sensitive to IAA (16). We propose that bacteria colonize stems and produce IAA, which in turn loosens cell walls of the phloem and cortex, thereby allowing cell hypertrophy. Then, presumably cytokinin, of bacterial and/or plant origin, induces hyperplasia. The rapidly growing and dividing cells exert pressure on the rigid periderm, causing it to split and slough from stems. Water conductance in hardwood species depends to a great extent on the current year's earlywood vessels (21). Where water is not limited, conductance is more efficient through wider vessels than narrow vessels. Although the newly differentiated xylem in galls was sometimes contiguous with axial xylem, death of tissues distal to galls suggests that water movement was restricted in galled portions of stems. Dieback from cranberry stem gall is likely due to the inability of narrow earlywood vessels to sustain tissues distal to galls and desiccation from loss of the protective periderm. In the field, dieback occurs during the period of bloom and fruit development, times when the demand for water is probably greatest.

Stem gall symptoms often are associated with mechanical damage from the previous year's harvest. Until our work demonstrating IAA-producing bacteria as the likely cause of stem gall (18), the prevailing belief was that stem swelling was caused by wound callus tissue. In woody plants, wound periderm is characterized by the formation of ligno-suberized cells internal to the wound surface, usually within 14 to 28 days of wounding $(6,7)$. Sections of cranberry galls treated with neutral red, which stains suberin (13), revealed suberized tissue but only in healthy regions of the stem (e.g., in the phelloderm) and not in gall tissue or within wound periderms separating galls from healthy tissue (data not shown). These results suggest that the stem swelling characteristic of cranberry stem gall is not wound callus tissue.
In conclusion, our microscopic investigation of cranberry stem gall revealed numerous hallmarks of pathological growth and large colonies of bacteria in galls, features similar to well-characterized galls caused by IAA-producing bacteria $(5,11,15,19,20)$. These anatomical data and pathogenicity tests (18) strongly support our hypothesis that IAA-producing bacteria cause cranberry stem gall.

\section{ACKNOWLEDGMENTS}

This project was supported by Hatch project WIS04448 through the College of Agricultural and Life Sciences, University of WisconsinMadison. We thank R. Spear and H. Simon for advice on histology and microscopy; E. Zeldin for advice on micropropagation of cranberry; and F. Caruso for providing gall samples from Massachusetts.

\section{LITERATURE CITED}

1. Aloni, R. 1987. Differentiation of vascular tissues. Annu. Rev. Plant Physiol. 38:179-204.

2. Aloni, R. 1991. Wood formation in deciduous hardwood trees. Pages 175197 in: Physiology of Trees. A. S. Raghavendra, ed. Wiley, New York.

3. Aloni, R. 1993. The role of cytokinin in organized differentiation of vascular tissues. Aust. J. Plant Physiol. 20:601-608.

4. Aloni, R. 1995. The induction of vascular tissues by auxin and cytokinin. Pages 531-546 in: Plant Hormones: Physiology, Biochemistry, and Molecular Biology. P. J. Davies, ed. Kluwer Academic Publishers, Dordrecht, The Netherlands.

5. Aloni, R., Pradel, K. S., and Ullrich, C. I. 1995. The three-dimensional structure of vascular tissues in Agrobacterium tumefaciens-induced crown galls and in the host stems of Ricinus communis. Planta 196:597-605.

6. Biggs, A. R. 1985. Suberized boundary zones and the chronology of wound response in tree bark. Phytopathology 75:1191-1195.

7. Biggs, A. R. 1986. Phellogen regeneration in injured peach-tree bark. Ann. Bot. 57:463-470.

8. Biggs, A. R. 1993. Anatomy and histochemistry of wound responses in bark tissues and implications for management of canker diseases. Pages 13-33 in: Handbook of Cytology, Histology and Histochemistry of Fruit Tree Diseases. A. R. Biggs, ed. CRC Press, Boca Raton, FL.

9. Caruso, F. 1992. A new upright dieback in 1992. Massachusetts Cranberry Experiment Station newsletter (August). East Wareham, MA.

10. Coplin, D. L., and Kado, C. I. 2000. Pantoea. Pages 73-83 in: Laboratory Guide for Identification of Plant Pathogenic Bacteria. 3rd ed. N. W. Schaad, J. B. Jones, and W. Chun, eds. The American Phytopathological Society, St. Paul, MN.

11. Jones, S. B., and Fett, W. F. 1987. Bacterial pustule disease of soybean: Microscopy of pustule development in a susceptible cultivar. Phytopathology 77:266-274.

12. Lichter, A., Barash, I., Valinsky, L., and Manulis, S. 1995. The genes involved in cytokinin biosynthesis in Erwinia herbicola pv. gypsophilae: Characterization and role in gall formation. J. Bacteriol. 177:4457-4465.

13. Lulai, E. C., and Morgan, W. C. 1992. Histochemical probing of potato periderm with neutral red: A sensitive cytofluorochrome for the hydrophobic domain of suberin. Biotech. Histochem. 67:185-195.

14. Ruzin, S. E. 1999. Plant Microtechnique and Microscopy. Oxford University Press, New York.

15. Smith, E. F. 1920. The olive tubercle. Pages 389-412 in: An Introduction to Bacterial Diseases of Plants. W.B. Saunders Company, Philadelphia.

16. Srivastava, L. M. 2002. IAA and cambial activity. Pages 332-333 in: Plant Growth and Development: Hormones and Environment. Academic Press, San Diego.

17. Surico, G., Iacobellis, N. S., and Sisto, A. 1985. Studies on the role of indole-3-acetic acid and cytokinins in the formation of knots on olive and oleander plants by Pseudomonas syringae pv. savastanoi. Physiol. Plant Pathol. 26:309-320.

18. Vasanthakumar, A., and McManus, P. S. 2004. Indole-3-acetic acid-producing bacteria are associated with cranberry stem gall. Phytopathology 94:1164-1171.

19. Wilson, E. E. 1965. Pathological histogenesis in oleander tumors induced by Pseudomonas savastanoi. Phytopathology 55:1244-1249.

20. Wilson, E. E., and Magie, A. R. 1964. Systemic invasion of the host plant by the tumor-inducing bacterium, Pseudomonas savastanoi. Phytopathology 54:576-579.

21. Zimmermann, M. H. 1983. Efficiency versus safety. Pages 15-16 in: Xylem Structure and the Ascent of Sap. Springer-Verlag, Berlin, Heidelberg. 